\title{
Degradation or regeneration? Prospects for developing the port-city interface in Odesa
}

Seeking an optimum sustainable development strategy is a core objective of municipalities and innovative urban planners around the world. Various viewpoints and interests regarding the interface between ports and cities and the resulting extensive waterfront regeneration in principal seaports render spatial planning projects of this type complex to complete and obtain agreement on. For a modern city, port development is a principal source of influences and benefits related to ecology, society, and transportation. Currently, the world's largest seaports are moving cargo terminals out of historical city centres. As a result, ports are assuming more advanced functions unrelated to the maritime industry, and thus projects that equitably share port territories will naturally gain momentum. The most significant projects for moving cargo ports out of historical town centres and regenerating port areas are found in European cities. To understand the various approaches, examples from European regeneration projects for port territories in Bilbao, Barcelona, and Oslo are presented, and their experience with various geographical and town-planning conditions is highlighted. This study is devoted to the Ukrainian port city of Odesa. It identifies the most successful strategy for developing the port-city interface under current economic and geopolitical conditions. It combines the ideas and studies of city planners in management, economics, and transport geography along with various policies and sociology aspects to provide new information and understanding aimed at ensuring the sustainable development of coastal cities in developing countries.

Keywords: urban regeneration, port-city interface, waterfront regeneration projects, Odesa seaport, Ukraine 


\section{Introduction}

The regeneration of ports reflects a uniform strategy for the competitive development of twenty-first-century port cities. The globalization of the economy, focusing on the service sector, shows that port cities are becoming the main players in the battle for economic leadership. As a rule, seaside cities develop into laboratories for waterfront regeneration processes. The waterfronts of the leading port cities are being transformed from twentieth-century industrial zones and port terminals into residential, commercial, tourism, and recreational facilities. These cities offer new opportunities for innovative ideas and utilizing the most valuable coastal part of the city centre (Hoyle, 1989, 1998a, 1998b, 2000).

Currently, thirteen seaports are operating in Ukraine. Five ports located in Crimea are excluded from this study due to the annexation of this territory by Russia in 2014. Ukraine's seaports are spatially divided into five regional groups, serving adjacent industrial enterprises and domestic and international transport corridors. The largest group is the ports of Odesa, known as "Big Odesa" (the Odesa port agglomeration), which includes Odesa and the satellite towns of Yuzhne and Chornomorsk, accounting for about $54 \%$ of all turnover at Ukrainian seaports (Demyanchenko, 2013).

The port of Odesa is located in the centre of this large city, which has a population of over one million. Odesa developed on land conquered from the Ottoman Empire by the Russian Empire at the end of the eighteenth century. The port contributed to the rapid growth of the city on the northern coast of the Black Sea. The transition from communism to democracy and the disruption of economic ties were reflected in the sea freight industry. With the collapse of the USSR, turnover suddenly dropped to less than half its previous volume. The cargo capacities of the Odesa port agglomeration were designed to serve the Soviet Union, with a population of 250 million, whereas the population of modern Ukraine is less than 42 million (Internet 1, 2019). The seaport area and the length of the pier have remained the same, but the seaport equipment has become obsolete.

Ultimate failure to develop an effective strategy in the maritime industry and harmonize it with city planning resulted in the large-scale construction of grain terminals in the historical city centre, which has caused transportation and environmental pressures on the centre of Odesa. Such intervention in the planning structure of the city will have irreversible consequences and will lead to the degradation of the historical centre. The accumulation of large cargo projects in the port of Odesa is at odds with global trends in moving cargo terminals out of the city centre, and this therefore does not make it possible to alter their functional purpose for the city and, consequently, does not allow the port to serve the public interest. Because of the enormity of the port infrastructure in its current structure, its modernization and reconstruction demand considerable means. However, the ports of Ukraine have no such means, and state support for all ports is insufficient. The troublesome property relations in seaports, and intra-port and inter-port competition between various actors leads to confusion and the loss of freight traffic. In this time of globalization, the transformation of ports and their waterfronts is closely connected with global economic restructuring, technological changes in production, organizational process changes in the industry of coastal areas, and competition between cities in the global hierarchy (Schubert, 2011). Because transformation and its acceleration are irreversible, for Ukraine the beginning of positive change is only a matter of time. At the same time, delay is fraught with negative consequences.

This study analyses current concepts and projects related to regenerating port areas in major EU cities, emphasising the key prerequisites for carrying them out. It develops a spatial planning model for Ukraine's major port cities, such as Odesa, Mykolaiv, and Kherson, focusing on the influence of public institutions on processes at the port-city interface.

\section{Literature review}

Regeneration of port territories is becoming an increasingly interdisciplinary phenomenon in urban planning, and it requires the attention of various disciplines: geography (Hoyle, 2000), planning policies and strategies (Fainstein, 1994), environmental science (Georgison, 1995), architecture, ecology, and engineering (Hudson, 1996). Many studies (Breen \& Rigby, 1993, 1996; Davies \& Herbert, 1993; Ashton et al., 1994; Hasson \& Ley, 1994; Krausse, 1995; Norcliffe et al., 1996) show that the port-city interface has become a place where the struggle between various port and city forces achieves a substantial form. It is essential to involve stakeholders and the general public in planning and decision-making, starting from the initial stage of the concept discussions and pre-project solutions.

In Ukraine, the complex subject of port regeneration has not been thoroughly investigated; attention has only been turned to the general planning concept of coastal territories. Several previous studies have examined fundamental problems of the planning organization, construction, and reconstruction of coastal territories (Glazyrin, 1998, 2003; Onishchenko, 2008; Kirichenko, 2015). Alternative analyses have also examined resort and recreation zones in some articles (Panchenko, 1999, 2007; Urenev, 2003). One study analyses the state and devel- 
opment trends of Ukraine's sea trading ports (Demyanchenko, 2012, 2013). According to Brian S. Hoyle (2000), an expert on the port-city relationship, relocating seaports from the city centre and the revival of waterfronts is an evolutionary process that began in the 1960s in North America, in the 1980s in the seaside cities of Europe, and in the 1990s reached Japan, Australia, and South Africa. Waterfront regeneration projects have affected more than one hundred cities around the world. Most of these projects focus on the restoration of urban functions and are based on economic, ecological, and social studies (Hoyle, 2000).

Urban waterfront renewal projects create new relations between cities, their customs, and residents, and they offer unique opportunities to study harbours and new urban functions based on their economic, ecological, and social aspects (Oakley, 2011). Schubert (2009) identifies innovative technologies in marine transport that influence the conversion of embankments and port terminals to meet the needs of vessels and containers. Large-scale port area regeneration projects have taken place since the early 1980s. Because of increased automatization, the principal ports have become less significant on the urban market. This is one of the key reasons why principal cities are now less dependent on port terminals for local economic growth (Jacobs et al., 2010). To a greater extent in the world's most significant ports, local employment rarely exceeds a few thousand jobs. Several trends, including containerization, automation, and economies of scale, have made port operations more capital intensive and land-based, but less labour intensive. Over the past decades, many ports have become more productive and competitive (Merk, 2013).

Many port cities promote activities relating to tourism as an alternative to a commercial cargo port and its related shipping activities (McCarthy, 1996, 1998). This is occurring across Europe and in many cities around the world. Especially impressive changes have occurred in Mediterranean cities, which have increased in importance for the global development of tourism. According to Daamen and Vries (2012), regenerating port territories demands special attention because these places are widely recognized as some of the most challenging in modern spatial management and planning.

A variety of environmental impacts are related to a port's activity, such as shipping activity in the port, activity on the port's land, and transport to and from the port. The main impacts are related to air pollution, water quality, soil, waste, biodiversity, and noise. These environmental issues can have severe consequences on the health of the population in a port city, especially in poorer neighbourhoods (Merk, 2010). Brand (2007) argues that changing the role of coastal zones in urban canvases makes one think of the relationship between city and sea as one of the main environmental issues of the twenty-first century.

Currently, deindustrialization is a critical orientation in projects to transform a coastal city's waterfront. Key cities adopt a similar method of urban evolution: the industrial port moves from the centre to territory claimed from the sea, thus freeing spaces for cultural, commercial and tourist sites in the old port zone. In line with the city's sustainable development strategy, the process of business diversification and its profound impact on the social environment is inevitable. The terms regeneration, renovation, revitalization, and redevelopment have many values connected with various processes and planning solutions. However, in the context of port territories, they are united by a uniform "evolutionary" process involving the new use and function of deindustrialized territory. The model of city-port evolution (Hoyle, 2000) shows a chronological character of the relationship and, in the final stage, cooperation between the port and the city is resumed and continuous, the waterfront becomes dynamic, and the port moves from the centre to more convenient areas. These fundamental characteristics of the processes and phases of re-planning the waterfront reflect patterns of urban development around the world.

The considerable improvement of a port's function leads to renovated and extended passenger terminals, reduced military harbours, and the relocation of cargo capacities from the centre to the city's suburbs. Areas that port activity is relocated from change their functions from production to public, business, and recreation. Ports that were previously inaccessible to the public and cut off from the city by railways and highways now become active, turning into hubs with various types of recreation and entertainment activities. Newly constructed residential and office buildings, and cultural and art venues become accessible to the public and tourists.

\section{Methodology}

The processes on the border between a port and a city are some of the most difficult in modern spatial management and planning. To maintain an appealing city and its competitive capacity in a globalized world, regenerating deindustrialized port territory is inevitable and unavoidable. Therefore, in the earliest stages it is necessary to focus on the activities of various social movements, municipal authorities, and designers to permit the change required of waterfronts. We investigate factors and the phenomena that precede the regeneration of port territories in developed countries. In addition, we examine the reasons for changes in the port-city interface in developing countries oriented toward exporting raw materials rather than the service sector. It is necessary to develop methods to 


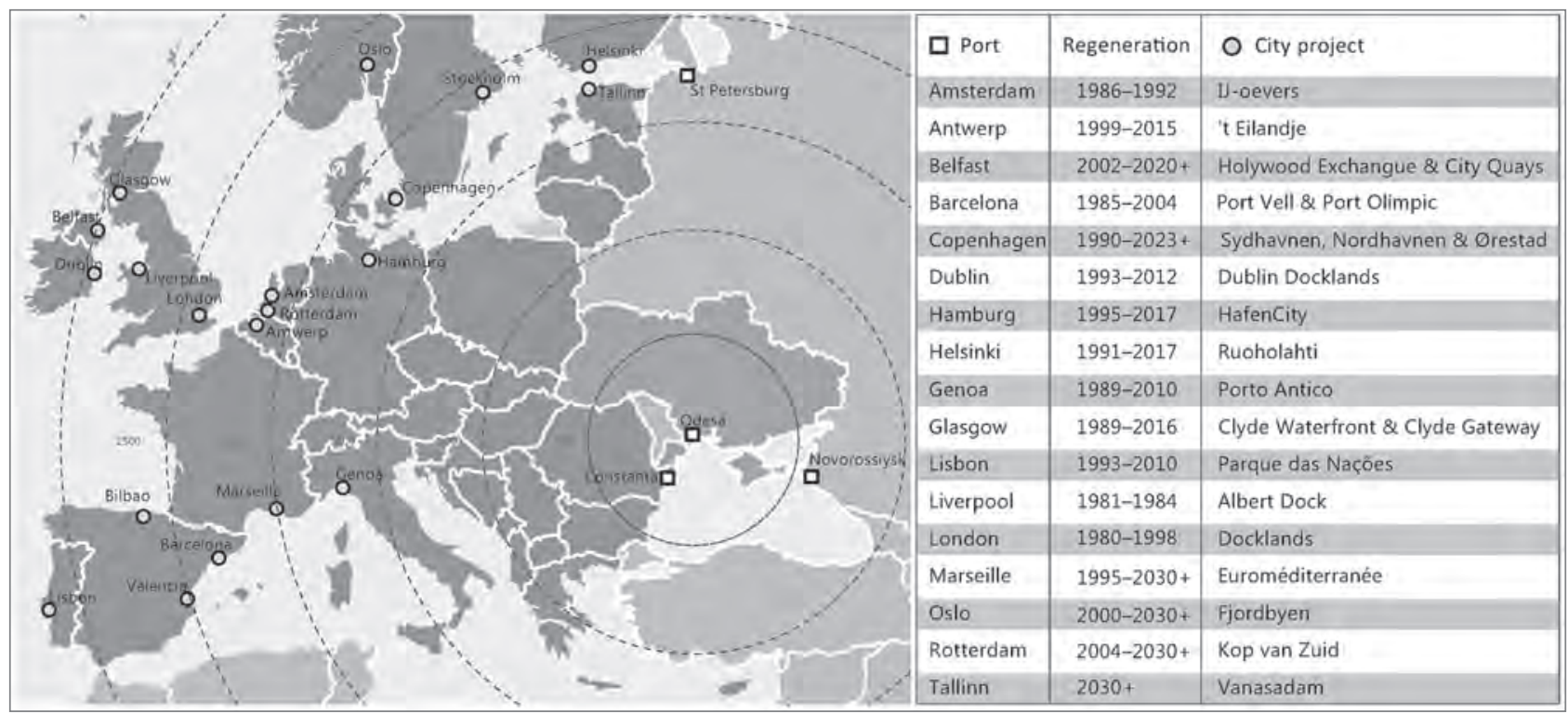

Figure 1: EU port regeneration projects (illustration: Vladimir Khalin).

\section{European port regeneration projects}

consolidate all of a port's and industrial territory's participants for effective regeneration.

Empirical work included inventorying and coding documents (spatial plans and concepts, news articles, associated reports, and publications), holding an open discussion with representatives of the port's authorities and state bodies, and public surveys. Documents are constantly updated and published on the website of the non-profit Odesa Architects' Association (2019).

To identify the most appropriate strategy for developing a port-city interface in developing countries and, in particular, in the port cities of Ukraine, we conducted an in-depth analysis of twenty successful projects in major EU cities. The most typical regeneration projects in different geographical and planning conditions are presented in this article; namely, in Bilbao (at the mouth of a river), Barcelona (on the open sea), and Oslo (in a fjord). In the graphic part of the study, we propose adjusting cargo capacity to the scale of the Odesa agglomeration and we consider the long-term regeneration prospects of the Odesa port area by applying a SWOT analysis. The results of this research have been considered in academia and presented at international conferences. Part of the research was presented to experts at the World Bank by request of the Odesa city authorities and seaport (Internet 2, 2019).
Regeneration of port zones in Europe involves restoring the original relations of the city and port when the port was the centre of trade and communication for residents. Marine facilities and transport, the railroad area, docks, warehouses, and factories had exclusive access to the waterfront. The situation changed in 1960, when a global transformation of marine facilities and large-capacity technologies took place. As sea vessels became larger, they required deeper waters and more extensive land and water sites. This forced ports to migrate some distance toward deeper water, to reclaim land from the sea, and to use more modern operational technologies. Key European projects on regenerating port areas in large cities show various models of converting the port-city interface (Figure 1). Many coastal cities underwent rezoning regardless of their port activities, making coastal sections off-limit to industrial facilities. For ports on rivers, enhancing sea technology meant relocating facilities downstream (Hoyle, 2000).

Many ports in large European cities operate as landlords. That is, the port administration acts as the manager of the land that borders the port's water area. It allocates sites to port operators in terms of licensing, charges fees depending on the value of sites and their location, and collects payments. As a rule, in such ports, the municipal or regional administration is involved in port administration and is part of the supervisory board. The role of the national, regional, and municipal authorities in carrying out regeneration projects is dependent in many 


\begin{tabular}{|c|c|c|c|c|}
\hline Stage & Port Vell & Period & Symbol & Characteristic \\
\hline $\begin{array}{l}\text { Primitive } \\
\text { port city }\end{array}$ & 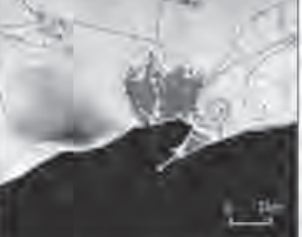 & $\begin{array}{l}\text { Antiquity / } \\
\text { Middle Ages } \\
\text { to } \\
\text { nineteenth } \\
\text { century }\end{array}$ & & $\begin{array}{l}\text { Spatial and functional connection between } \\
\text { the city and the port. } \\
\text { The embankment: a place of communication } \\
\text { and commerce. }\end{array}$ \\
\hline $\begin{array}{l}\text { Expansion } \\
\text { of the port city }\end{array}$ & 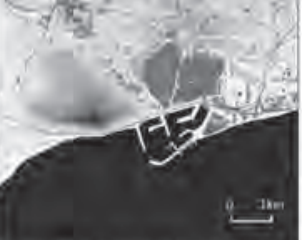 & $\begin{array}{l}\text { Nineteenth } \\
\text { century to } \\
\text { beginning } \\
\text { of twentieth } \\
\text { century }\end{array}$ & & $\begin{array}{l}\text { The industrial capacity of the port continues } \\
\text { to develop toward the sea. Linear piers for } \\
\text { bulk cargoes are built. The city is cut off from } \\
\text { the port by rail. }\end{array}$ \\
\hline $\begin{array}{l}\text { Modern } \\
\text { industrial port }\end{array}$ & a & $\begin{array}{l}\text { Mid- } \\
\text { twentieth } \\
\text { century }\end{array}$ & & $\begin{array}{l}\text { Growth of industrial production in the port. } \\
\text { The introduction of ro-ro containers and } \\
\text { vessels requires the separation of cargo flows } \\
\text { and new territories and terminals. Railways } \\
\text { and highways increasingly cut off the city. }\end{array}$ \\
\hline $\begin{array}{l}\text { Retreat from the } \\
\text { waterfront }\end{array}$ & $\stackrel{2000}{\longrightarrow}$ & $1960-1980$ & & $\begin{array}{l}\text { Changes in marine technology and an } \\
\text { increase in the size of ships causes an increase } \\
\text { in industrial berths in new bulk areas. Access } \\
\text { to the industrial port is finally closed to city } \\
\text { residents. }\end{array}$ \\
\hline $\begin{array}{l}\text { Waterfront } \\
\text { redevelopment }\end{array}$ & $3 \mathrm{~km}$ & $1970-1990$ & & $\begin{array}{l}\text { The modern port consumes large tracts of } \\
\text { land and moves toward the sea to deep } \\
\text { waters. The old port is not deep enough and } \\
\text { changes its functionality. Regeneration of the } \\
\text { waterfront of the historical centre. }\end{array}$ \\
\hline $\begin{array}{l}\text { Regeneration of } \\
\text { the port city }\end{array}$ & & $1980-2000+$ & & $\begin{array}{l}\text { Globalization and intermodality transform the } \\
\text { role of the port; the interconnection of the city } \\
\text { and the port is resumed; regeneration and } \\
\text { redevelopment enhance the integration of the } \\
\text { port and the city. }\end{array}$ \\
\hline
\end{tabular}

Figure 2: Stages of the evolving relationship between the port and city in Barcelona (illustration: Vladimir Khalin based on Hoyle's model).

respects on the country's territorial system and the distribution of power between various levels. In several European countries, special structures have been created to aid regeneration projects within regions. To understand the various approaches, we give examples from the European regeneration of port territories and their experiences with various geographical and town-planning conditions: in Bilbao, Barcelona, and Oslo.

\subsection{Bilbao Ria 2000}

After the major industrial crisis of the 1980s, the Basque government, the government of the province of Biscay, and the city council of Bilbao, in cooperation with the central administration, approved the strategic plan for revitalising the city by developing environmental, transportation, and urban 


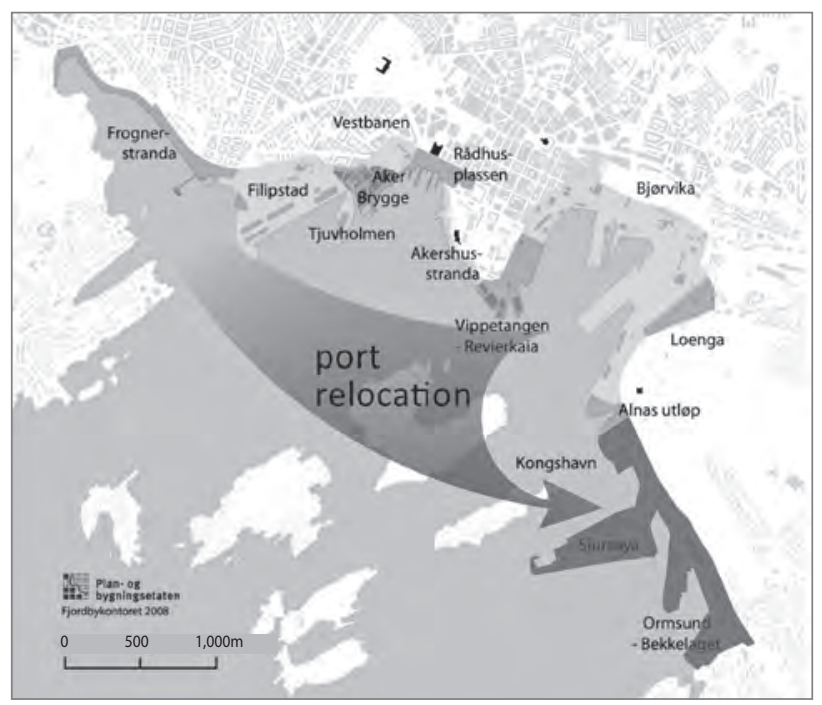

Figure 3: The Fjord City project in Oslo (source: Internet 3, 2019).

design projects. The process began in 1992 with establishing Bilbao Ria 2000 (Public Company Responsible for Urban Regeneration), an agency to mediate between the state and business providers. The program involves the combined efforts of the governments of Spain, and the Basque Country, the council of the province of Biscay, and the city councils of Bilbao and neighbouring Baracaldo. Mediation was established between the state and business. The port administration was transformed into a joint-stock company almost immediately, and so large-scale infrastructure, planning, and architectural projects became a primary instrument for modernizing Bilbao. Carrying out the port construction and the resulting redesign of the main transport corridor network have contributed to the city of Bilbao now returning to the river and its embankments.

A key point for the radical reconstruction was targeting territories along the river where regular port activities were no longer conducted. According to the plan, the river then became the centre point and focus for all new commercial and social activity. The planning included restoring the abandoned industrial enterprises and their surrounding area. The administration transferred the port territories downstream and allocated the freed-up space for social purposes. Creation of an economic structure concentrating on services, culture, and new industries represented the beginning of regenerating the urban areas. The embankments were subject to an order-planning strategy involving ecological and economic improvements. The project for renovating the port territory was named Bilbao RIA 2000. This non-profit organisation oversees and administers all interactions at all levels of the process. Bilbao Ria 2000 is responsible for coordinating and carrying out many activities integrating planning, transport, and the environment. Members of the company have developed projects with a global approach based on city planning recommendations.

\subsection{Port Vell, Barcelona}

As a classic example of the direct interaction of a city and a port, with many parameters similar to the port of Odesa, it is feasible to consider the reconstruction of the historical Port Vell in Barcelona. In the early 1980s, the administration of the port of Barcelona faced a choice between reconstructing the historical Port Vell to meet the modern requirements of freight processing and relocating the port's cargo capacities west of the centre, thus giving the town's residents access to the waterfront. The proposal to make the waterfront available to residents and tourists was successful, and it has profoundly influenced the city's economic development. To promote the port's area renovation, the project group established by the port set up a special management body in 1985. The fact that the city council completely cooperated with the plans for the port helped overcome bureaucratic difficulties associated with the reconstruction. The final coordination and adoption of re-planning by the government of Catalonia was finalized by the middle of 1989 (Fig. 2).

As part of extensive preparations for the 1992 Summer Olympics, the old port area was reconstructed as a walking and recreational zone. The centre and the city's northern part are off-limit to cargo terminals. The administration of the port has expanded access to the waterfront for all residents and tourists in the central part of the city, which is now regarded as an accessible urban environment where tradition merges with contemporaneity, and as a unique and favourite place in Barcelona. Over the centuries, the port of Barcelona played an active role in shaping the future city by transforming into a comfortable location for people and facilitating economic prosperity (Port de Barcelona, 2010). Barcelona used the 1992 Summer Olympics to transform the port-city interface and integrate the embankment's development with the long-term planning strategy. The experiment in renovating Port Vell shows that developing a diversified business model improved the port's competitiveness.

\subsection{The Fjord City project in Oslo}

A blue fjord characterizes the Norwegian capital of Oslo. Until the twentieth century, the shipyard and its structures blocked public access to the waterfront. Opinions on the gradual development of a city's waterfront at the levels of the municipal authority and port administration usually do not coincide. Coordinating official positions and specific viewpoints often takes decades. In Oslo, the negotiation process and coordinating the positions to suit everyone took place between 1982 and 2008. The port of Oslo owns the waterfront and remains the main beneficiary of economic activity, and it therefore has a vested interest in the port's activities and its development. The port's 


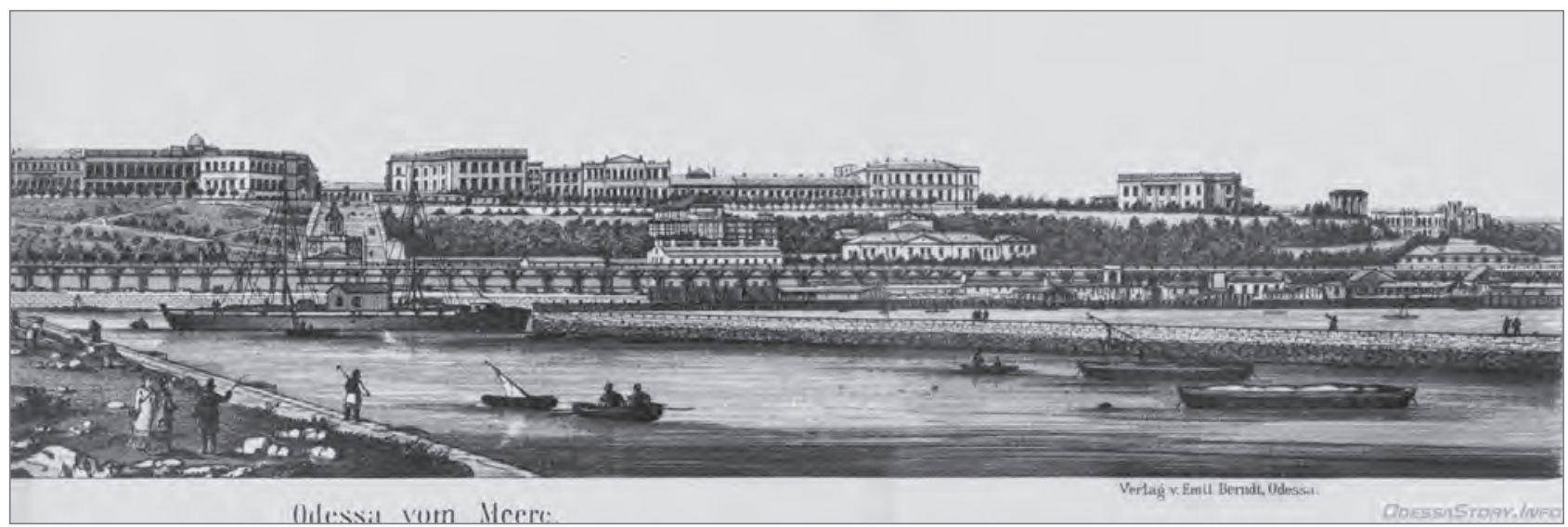

Figure 4: Old engraving of Primorsky Boulevard (source: Internet 5, 2019).

management includes representatives of various levels of the port authority and the local municipality. Therefore, the city authorities can directly or indirectly influence the port's decisions (De Vibe et al., 2008).

Historically, Norwegians prefer naturally designed landscapes rather than industrial facilities as a symbol of the city's identity. This point became an essential factor for decision-making on the port's relocation from the city centre. On 19 January 2000, a large-scale harbour reconstruction programme called Fjord City (Norwegian: Fjordbyen) started. The waterfront has turned into an attractive area with housing, offices, and cultural institutions. The Oslo City Council made the decision that the port and industrial territories must be available for the city development program and become part of the city landscape. The Fjord City project is so multi-layered and complex that for its implementation the municipal authorities are using various approaches. The municipality acts as the land's owner, and the builder must comply with strict requirements of public spaces and their availability when purchasing a site. In general, a private site owner has more planning options when the city council's budget is limited. Therefore, within this scenario, the council has to implement a compulsory purchase order through a public/private partnership, implement changes within this partnership, and then transfer the ownership to the city. In this case, the infrastructure is designed at the expense of the builder and transferred to the ownership of the municipality. These requirements inflate the cost per square meter but make it possible to provide investments for social needs (i.e., schools and green zones).

The decisions resulted in regenerating Oslo's waterfront. The port of Oslo is a crucial part of a national economy that requires important internal and external commercial relations. As part of the port's relocation, Oslo transferred the container terminal to the south along the east side of the fjord. Passenger, fishing boat, sailboat, and military ship sections are integral components of the city's waterfront and create the concept of
Fjord City. The modern port with new mooring depths and technologies for freight transfer will not overburden the city's infrastructure. By 2030, Oslo will receive not only a new part of the city, but also a new and modern port (Gisle Rekdal, 2013; Internet 3, 2019; Internet 4, 2019).

Today the critical problem in the changes affecting port cities is an inability to accept the requirements of port development, global practices, and urban development. According to Hoyle (1989, 2000), in recent decades the process of transforming ports has stemmed from wider and more independent trends:

- The evolution of maritime technology and considerably larger vessel sizes have contributed to extensive development of container processing methods;

- Modern cargo transportation does not use modern ports to their full capacity; and

- The reduction of port staff leads to restructuring of the urban economy.

The government gives priority to the development of transport and logistics enterprises at all levels and has preferences in decision-making when planning the city. In the world of small and medium-sized enterprises (including the media, information and communications technology, film, music, design, and tourism), forward-thinking development is key. These enterprises are the foundation of development and change in a city. The successful economic development of expanding cities in the twenty-first century depends on improving the quality of life for residents by attracting a strong concentration of diverse business sectors and educational institutions while also providing a wide array of leisure and relaxation facilities. Therefore, for cities and regions, there is a need to maintain competitiveness in the international market by maintaining national properties. The city plans places for work, housing, and relaxation, whose quality attracts the "creative class" (Florida, 2005; Peck, 2005). These knowledge-based societies then become a direct reflection of the globalization process. 


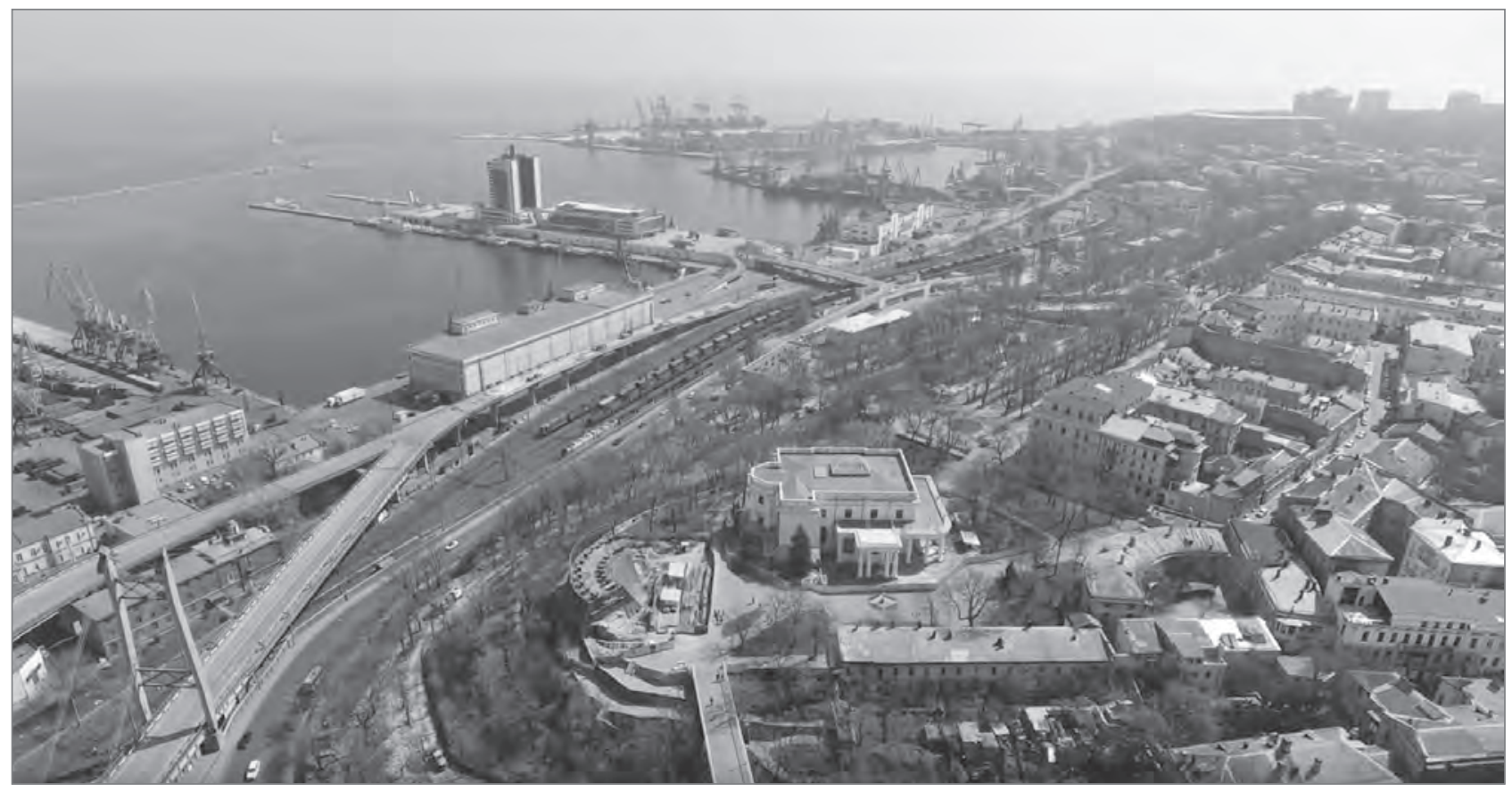

Figure 5: The new pier and Primorsky Boulevard (photo: Vladimir Khalin).

\section{The port-city interface in Odesa: development strategies}

\subsection{The study area: geographical and historical circumstances of Odesa's port development}

In the nineteenth century, Odesa's position on the Black Sea turned it into a commercial and cultural frontier between the Russian Empire and the rest of the world. The city was founded on a rocky plateau that rises over fifty metres above the smooth sea. The seaport became a centre of transportation and social life, which sharply contrasted with the steep open spaces of the northern Black Sea coast. As a young city, Odesa quickly gained a solid reputation as a modern city thanks to the architectural complex of Primorsky Boulevard, which holds a prominent place in world heritage. At the beginning of the twentieth century, due to industrialization, the port gradually lost its connection with the city. Access to the port was restricted by a railway and a wooden ramp overpass. In 1927 the port limited public access, and in 1947 it was completely closed to the public. Thus, the port lost communication with the city, and residents were unable to access the $10 \mathrm{~km}$ long waterfront.

The estuaries that form Odesa's geography were created by shallow narrow rivers and the sea's sandpits. In 1956, Aleksey Yevgeniyevich Danchenko, the head of the Black Sea Shipping Company, introduced the idea of moving bulk cargo from Odesa to Sukhyi Lyman (literally, 'dry estuary'), which adjoins the city borders and is located $30 \mathrm{~km}$ from the port of Odesa. The authorities of the Ukrainian SSR supported the proposition. Thus, the port of Illichivsk (today Chornomorsk) was established as an alternative gateway. In the 1960s dredging work was carried out to deepen the bottoms of the estuaries, which made it possible to partially remove the cargo terminals and to build two larger ports: Yuzhne and Chornomorsk. Removing cargo capacities from Odesa's city centre began with the first port, at the same time as projects to regenerate industrial areas in North America. Regrettably, this was not accomplished because the Soviet planned economy was inflexible; no initiative from a private business could result in changes in city planning. At present, geographical advantages in the form of convenient estuaries for developing cargo ports show the unique opportunities for the Odesa agglomeration to become the largest transport and logistics hub in the Black Sea Basin. Eight of the total of thirteen seaports in Ukraine can be found in the Odesa region. The port of Odesa is located in the open sea gulf, three ports are in estuaries (Chornomorsk, Bilhorod-Dnistrovskyi, and Yuzhne), and the remaining four are built on rivers.

During the post-Soviet period (from the beginning of the 1990s), the following sequence of events can be observed at the port of Odesa:

- Operation of berths and terminals without specialization dictated by the needs of private business tenants of the state port;

- Abandoned areas;

- Lack of a consistent port development strategy; 


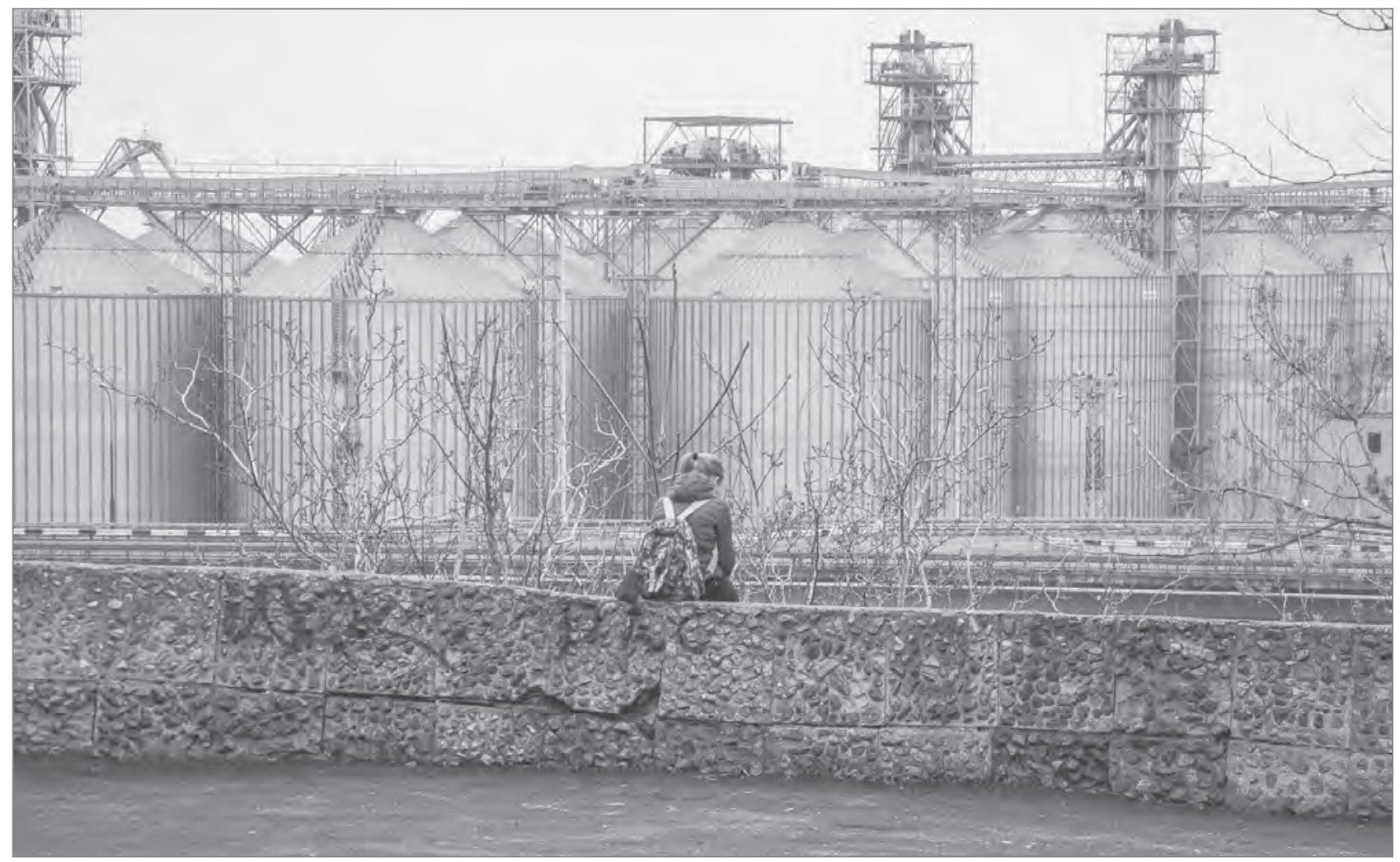

Figure 6: Construction of grain terminals in the centre of Odesa (photo: Stanislav Gref).

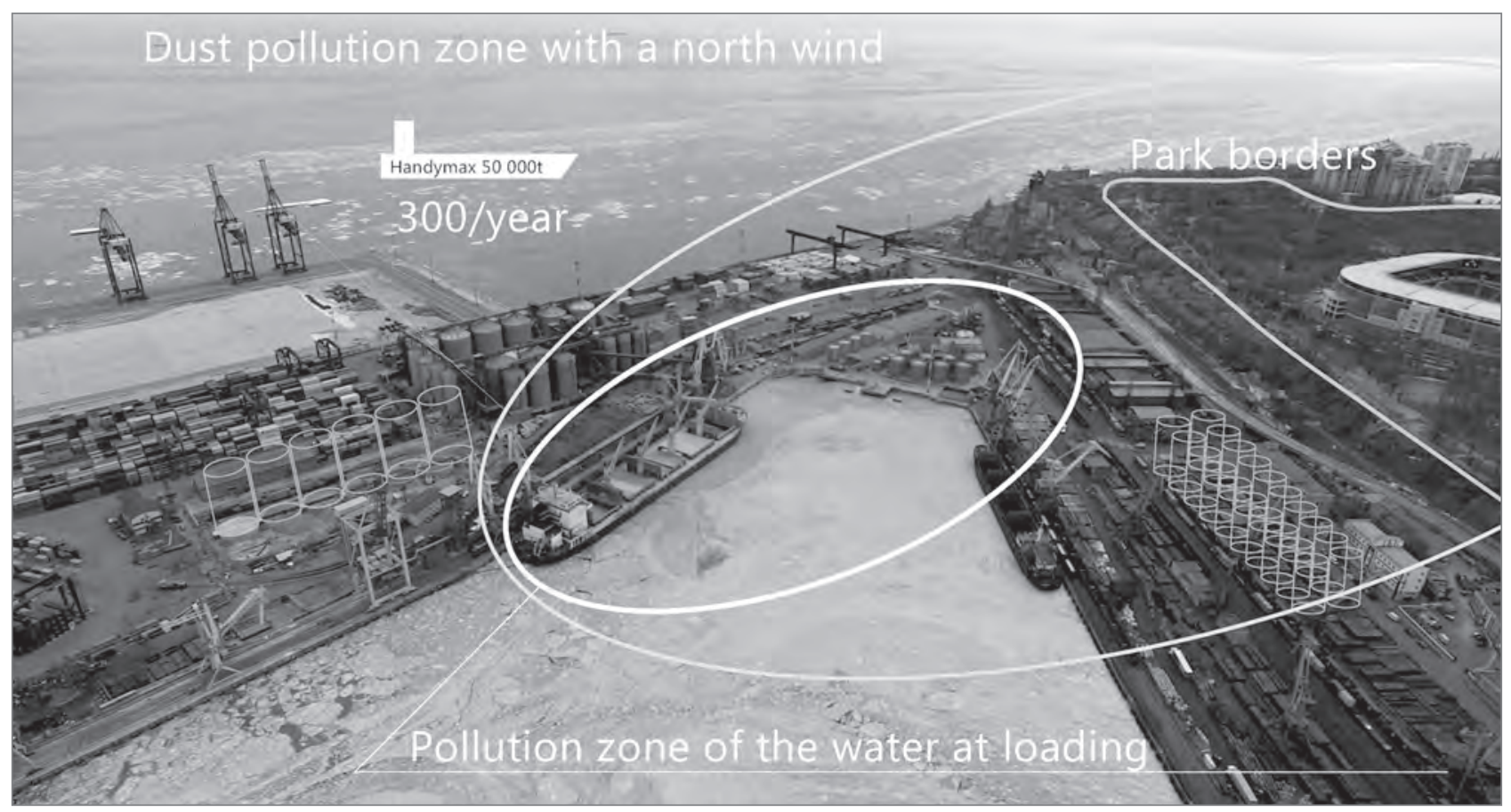

Figure 7: Dust pollution of the water area and the city when loading grain on a Handymax vessel (photo: Vladimir Khalin).

- Growth of bulk cargo terminals;

- Increasing the port area for the construction of new sites for container terminals on land reclaimed from the sea; and

- Growth of transport, the ecological burden, and noise pollution affecting the city.

\subsection{Degradation of the city-port interface}

In recent years, Ukraine has been actively attracting public funding for infrastructure projects. Undeniably, one often-used argument is that infrastructure development alters regional progress and economic growth. Projects implemented 


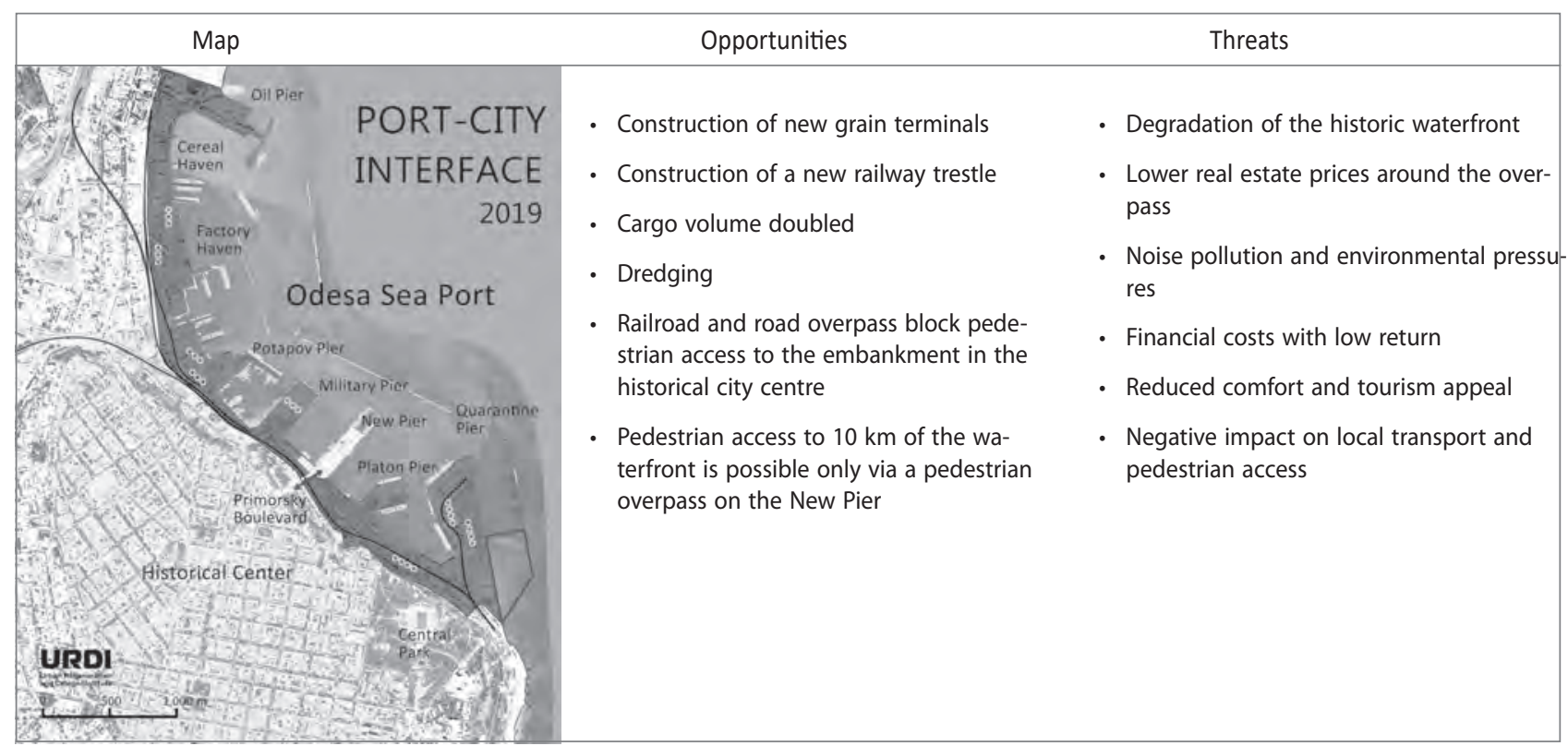

Figure 8: Assessment of the port development strategy (illustration: Vladimir Khalin and Natalie Kiely).

on the terms of a public-private partnership do not correspond to the concept of sustainable development of a city with a population of one million. Instead of removing bulk cargo from the historical centre, grain terminals are being built along the entire port waterfront. Projects for building grain terminals in the port (at present there are nine of them) will cover the entire waterfront in the city centre. (Fig. 6.). The 45-metre-high grain silos block the historical centre from the sea. Not only are environmental threats recorded in Odesa's centre in the form of protein dust carried by prevailing north-easterly winds, but architectural concepts such as the "marine facade of the city" and the "sea view" are also no longer applicable to the city.

A study of the port of Odesa operation conducted by experts of the World Bank led by Peter Bingham showed that the most active loading of ships coincides with adverse winds (Internet 2, 2019). At the same time, when justifying the need for these projects, the fact that the capacity utilization of all grain terminals in Ukraine was only $86 \%$ is not taken into account. Such figures indicate that there is no capacity shortage in the grain transhipment market. However, the grain market has high margins of return, which means that projects will continue to be implemented by participants in the raw materials business. It is expected that by the end of 2018 the growth rates of the capacities will be much faster than the growth rates of grain exports. Accordingly, loading of terminals will decrease, and by 2020 the existing surplus of capacities will grow in the grain export market. This means that projects implemented in the city's most valuable areas will not be economically feasible.

At present, world trade and outsourcing are rapidly expanding thanks to continuous improvement of the efficiency of the sup- ply chain and its transport component. However, in addition to modern transport technologies, low prices for cargo delivery are explained by the fact that some expenses are covered by taxpayers. The following hidden costs can be attributed to port, car, and rail infrastructure: congestion in ports, air pollution, and subsequent healthcare costs. The example of Ukraine is indicative. Grain exports of about 40 million tonnes per year, the bulk of which is delivered by road transport to the Black Sea ports, results in wear and tear on roads and creates congestion in port territories. These factors should be borne in mind when designing port development programs. Considering that the development of the transport and logistics infrastructure system is not only one of the most urgent tasks in developing countries, but that it also involves tremendous risk (from a both democratic and a pragmatic point of view), the public must be attracted to and involved in the decision-making in every possible way. Sustainable development of the port city of Odesa is impossible without decentralizing the city-port system. Similar projects require the redistribution of public and private obligations to strengthen accountability. The review of development projects in the port of Odesa (Odesa Sea Port Authority, 2019) makes it possible to identify the following opportunities and threats (Figure 8).

The main role of the government and municipal authorities should not be to promote infrastructure projects lobbied for by raw material corporations. On the contrary, they should keep the project and its participants at arm's length. Thus, at each stage of the project they must evaluate whether it fulfils the purposes and requirements of the public interest and is consistent with the legislative and regulatory acts concerning protection of the environment, safety, and savings. Existing 


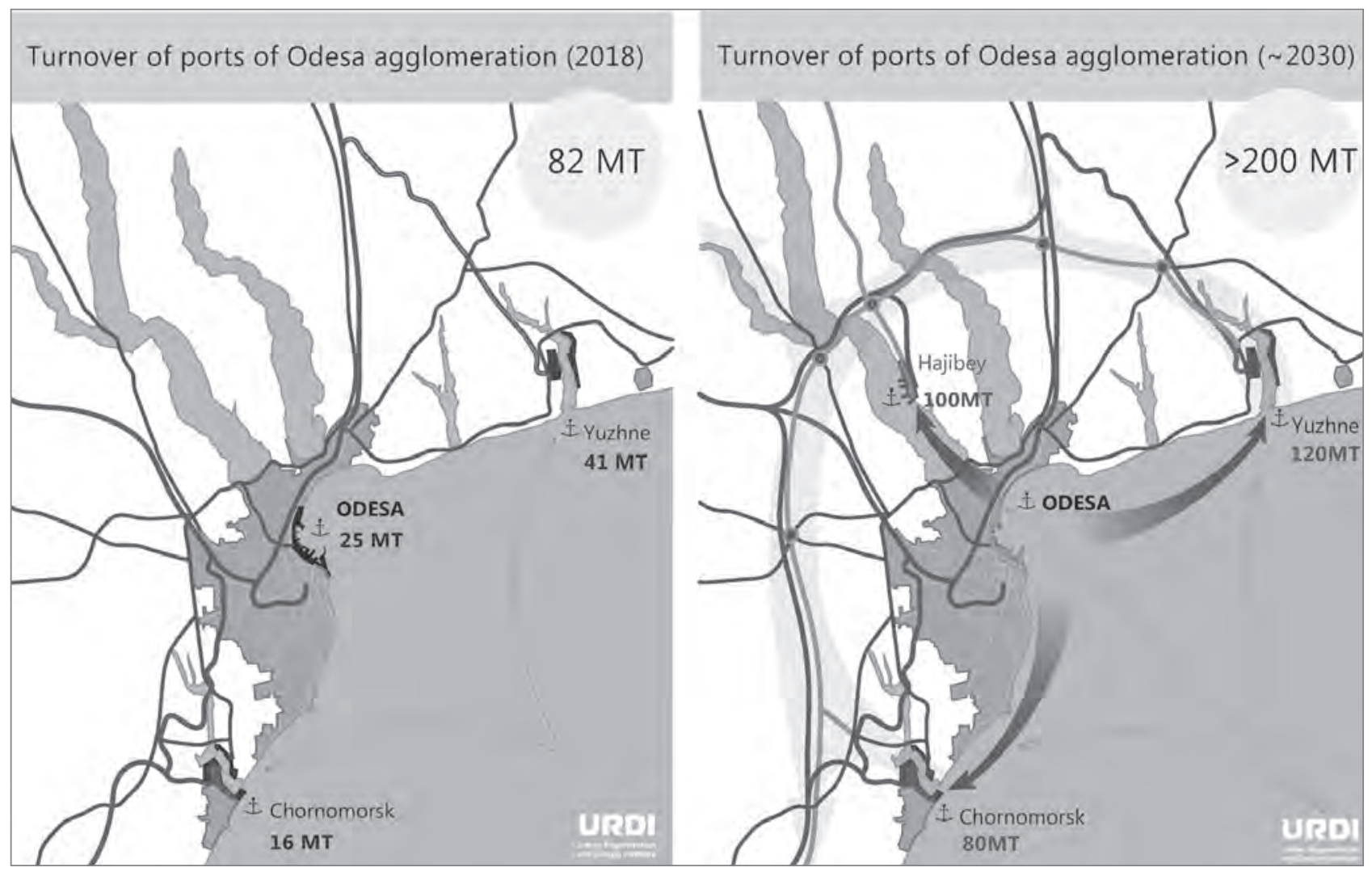

Figure 9: Transport and logistics in the structure of the Odesa agglomeration, 2018-2030+ (illustration: Vladimir Khalin and Natalie Kiely). Note: MT = million tonnes.

concepts (Ports of Ukraine, 2019) for the further development of the port are based on bulk area expansion and do not answer a main town-planning question: how, under conditions of dense urban development, does one provide transport communications with the mainland and deep-water terminals?

\subsection{Regeneration of port territories}

Urban and territorial planning is one of the most important investments in the future, a prerequisite for improving the quality of life and the successful implementation of the globalization process, respecting cultural heritage and cultural diversity, and understanding and taking into account the specific needs of different groups of the population.

In reality, the abandoned and unusable areas of Ukraine's current state ports are enormous. As an indicator of the efficiency of modern port technologies, one can compare the annual turnover of goods and the length of the Rotterdam port's berth, at 477 million tonnes $/ 57 \mathrm{~km}$. The same total indicator for all Ukrainian ports is just over one-third of that: 131 million tonnes / $40 \mathrm{~km}$. Establishing sites attractive to investment for a diversified business not directly related to port activities will inject life into these valuable territories, which will lead to exponential growth of jobs and, overall, increase Ukraine's welfare. The experience of Barcelona shows that when the Vell Port was renovated, the number of jobs increased by a factor of ten. Moreover, investment in port facilities and businesses' profits have increased. City residents, non-profit organizations, and municipal authorities need to show more initiative for a qualitative change to the environment. Participatory planning and budgeting, including communities in managing the common property of cities, such as public spaces and services, can enhance spatial integration and strengthen ties, security, vitality, local democracy, and social accountability.

Comparative characteristics of the initial data for regeneration projects at the ports of Odesa and Barcelona reveal a significant difference between the orientations of ports based on goods transhipment. The main cargo in Barcelona is containers, whereas in Odesa it is bulk. The most significant advantage of the ports of the Odesa agglomeration is their geographical position, which makes it possible to transfer all cargo capacities to satellite cities on estuaries such as Yuzhne and Chornomorsk, which are suitable for building hydraulic structures without damage or loss to freight traffic.

The existing depths in the ports of Yuzhne and Chornomorsk make it possible to accommodate large vessels. The declared capabilities of the port of Yuzhne (120 million tonnes) are 


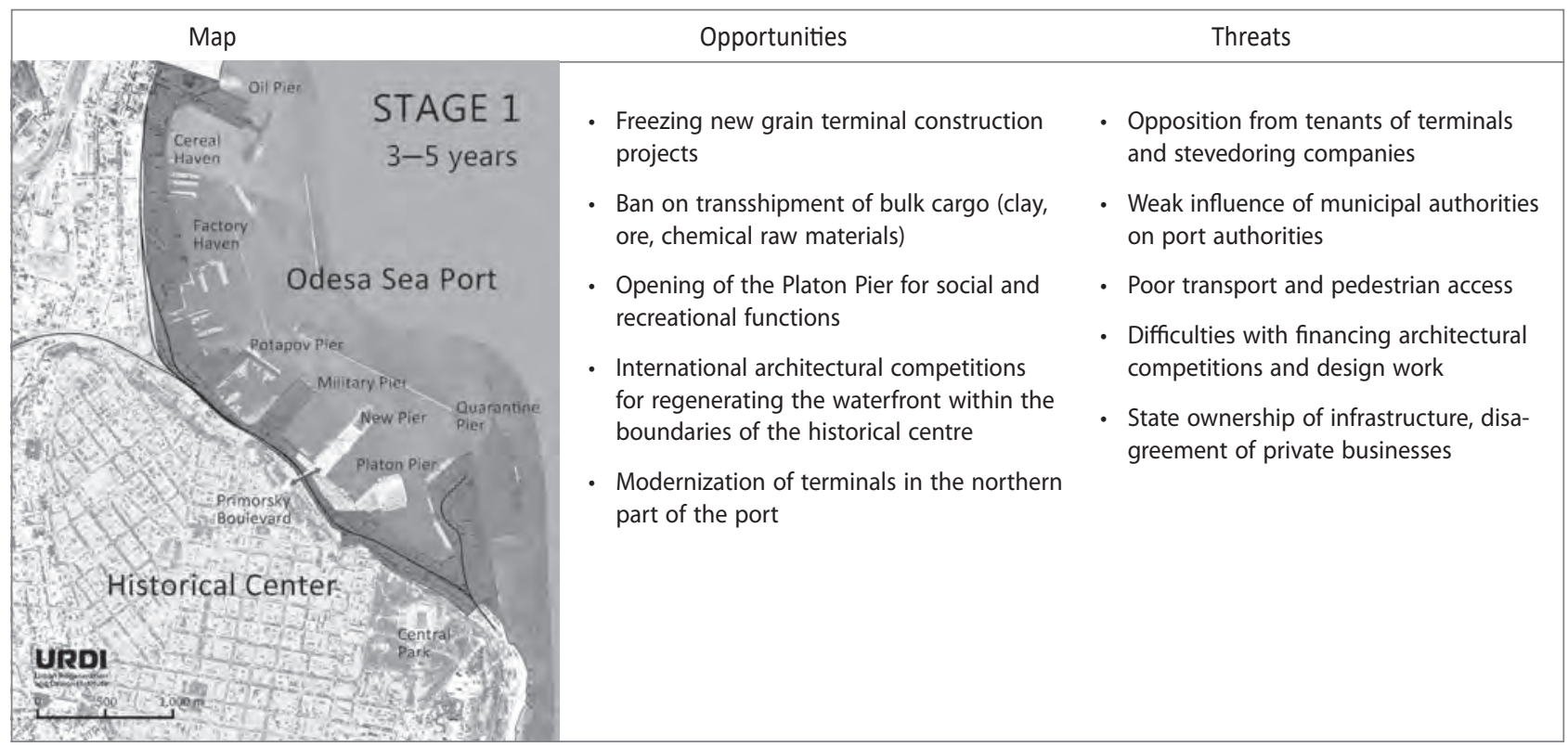

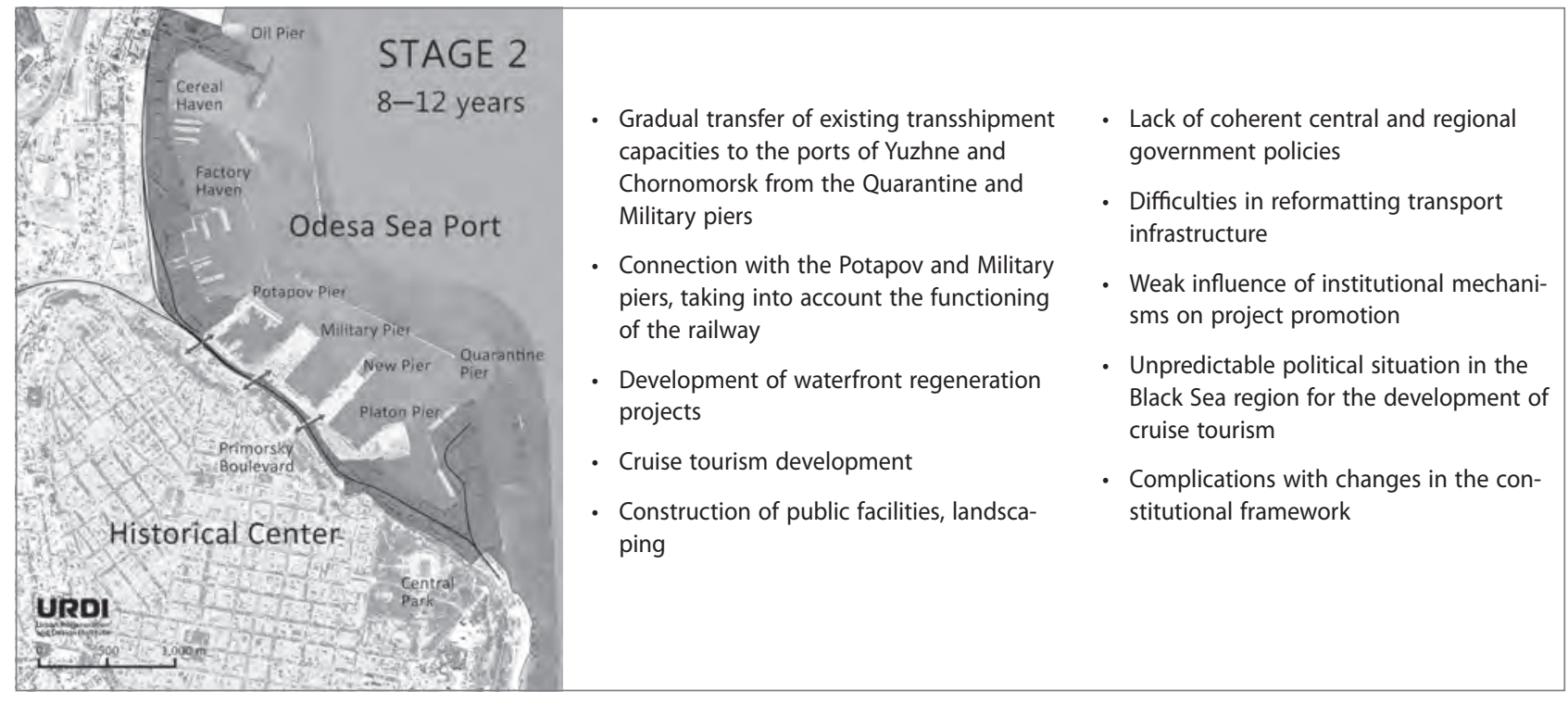

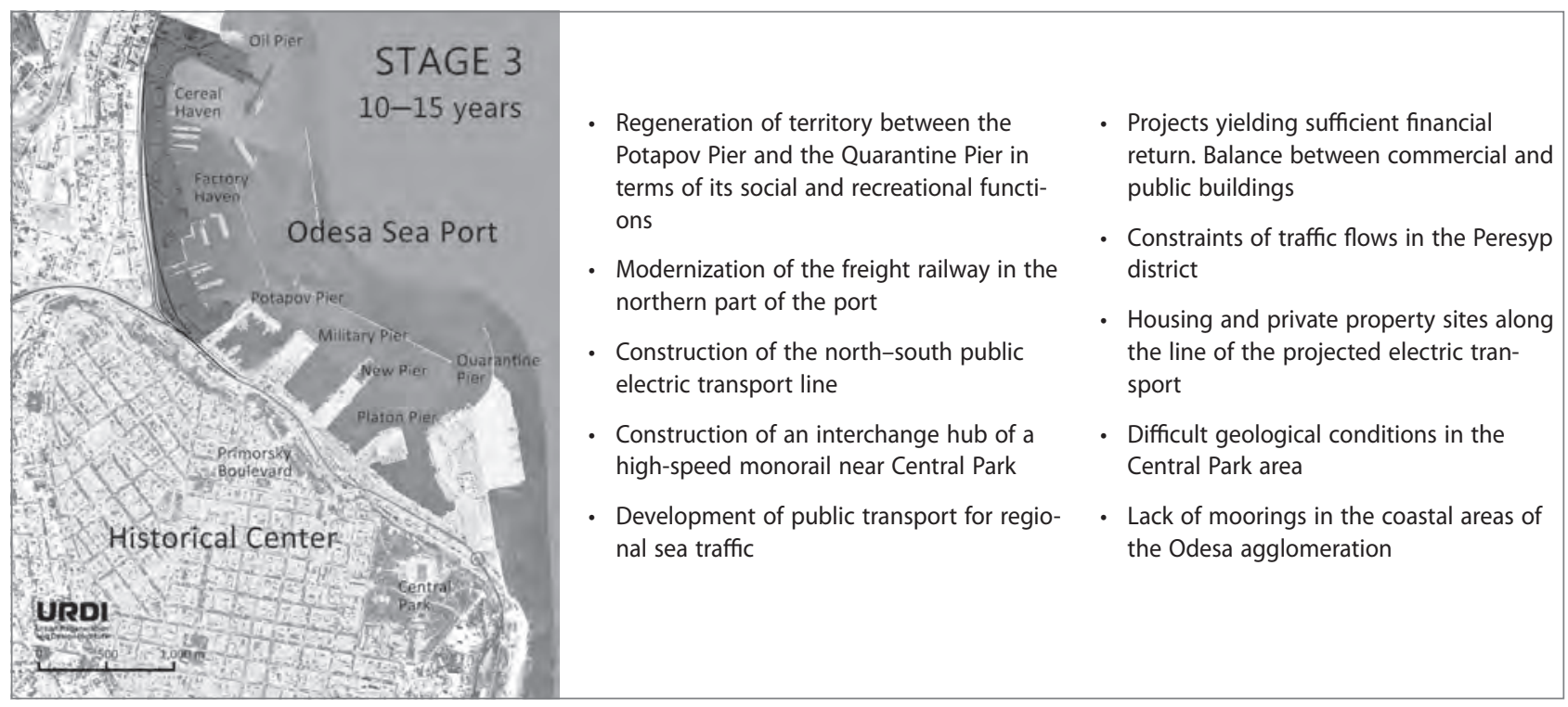

Figure 10: Evaluation of the project stages for the port area regeneration in Odesa (illustration: Vladimir Khalin and Natalie Kiely). 
almost equal to the entire 131 million tonnes existing cargo turnover of Ukraine (2016 data). The aggregated capacity of grain terminals in Ukrainian ports (66.2 million tonnes) already exceeds the entire annual grain harvest $(66$ million tonnes). Considering domestic consumption of about 30 million tonnes, the surplus of grain capacities of port terminals is already twice as large as export opportunities. Therefore, the construction of new grain terminals will only lead to the intra-port competition of stevedoring companies.

Some of the first steps taken in Odesa toward transforming the port in the post-industrial period were related to the idea of setting up a tourist hub on the Black Sea coast. This would allow Odesa to become a starting point where Mediterranean cruise routes would begin or end. In these conceptual designs it was proposed that the cargo port be transferred to the Khadzhibey Estuary (Skachek \& Freidlin, 2012), thus creating a transport and logistics centre in an area free from construction in the rear of the port. The relocation of the Odesa port $30 \mathrm{~km}$ deeper into the mainland would improve transport accessibility for cars and rail transport, reduce the impact on the landscape and the ecology of the city, and facilitate modern production near the new port outside the city. The modern port in these projects will be linked to the TEN-T trans-European transport corridors (Khalin, 2016), which corresponds to world trends in the development of a port interface.

In May 2018, the association of architects of Odesa held a panel discussion with students and teachers from Germany, and they held a roundtable forum called The Sea Cities in June. At the department of town planning of the Odesa State Academy of Civil Engineering and Architecture, every year three to four students select topics for their master's theses related to renovating port territories (Association of Architects of Odesa, 2019). An international architectural competition on the renovation of port territories, similar to a high-profile competition held in Tallinn, is necessary for meaningful feedback. Holding such a competition would position Odesa as a sustainable and democratic city. Port development or renovation projects should be integrated into regional and urban planning (Khalin, 2017). It is necessary to conduct interdisciplinary studies of the interrelation between the city and the port and to find the optimal solutions. Regeneration of port areas should be carried out step by step, taking into account the interests of all participants and maximum public benefit. Some reasonable proposals with regard to opportunities and potential risks are summarized in Figure 10.

\section{Conclusion}

In many cities that contain a port in their historical core, regenerating port areas begins with pressure from society, which develops into a discussion between civic organizations, the municipality, and the port administration. Such a discussion develops gradually, over ten to twenty years, and it has no significant impact on port business. It discusses the most suitable places for new terminals outside the city. Many abandoned shops and warehouses at the Odesa seaport can survive and flourish with functional changes. It is necessary to involve the city's representatives in the administration of the port, allowing it to make vital decisions in collaboration with all parties, including the local community. It is necessary to start cross-disciplinary studies. To begin with, these can be joint workshops involving students from various higher-education institutions, including those from foreign cities with experience in regenerating ports. A democratic society plays the principal role in launching institutional mechanisms for regenerating cities' waterfronts. This path has been taken by the most successful cities in the world, resulting in a high-quality landscape, diversified business, and public spaces emerging on the seafront. This appeals to the principal resource in the competitive struggle among the most prosperous twenty-first-century cities: creative people.

Exploring the successful European experience of regenerating ports in historical centres, we assume it is necessary to conduct more in-depth studies of the port-city interface in the developing countries of eastern Europe. Particularly for Ukrainian ports in large cities such as Odesa, Mykolaiv, and Kherson, we offer the following recommendations in planning and management:

- The structure of cargo flows through Ukraine's seaports reflects the real state of the country's economy, being an indicator of industrial development and the dynamics of the population's income level. In a growing post-Soviet economy, it is necessary to conduct interdisciplinary research to assess the repercussions of removing cargo terminals from historical city centres;

- The regulatory framework for port activities in Ukraine lags significantly behind the actual processes: the port's land belongs to the local government, and the port property to the national government. One way to address this issue is to create joint administrations to manage the port;

- The public should have more information about port development projects and their impact on social, environmental, economic, and cultural aspects. The public 
should be able to access objective information about the costs incurred by the city and the benefits it receives from port activities;

- The municipality should conduct independent research on the long-term future of port areas and select the appropriate option for sustainable development of the city;

- State management of ports in Ukraine makes it possible to specialize ports by types of cargo. The national government needs to design a long-term strategy for developing and specializing Ukraine's ports, considering the needs of urban planning and sustainable development.

Vladimir Khalin, Odesa State Academy of Civil Engineering and Architecture, Department of Town Planning, Odesa, Ukraine E-mail:khalin@ogasa.org.ua

Natalie Kiely, Cork, Ireland

E-mail: nataliekiely@eircom.net

\section{References}

Ashton, W., Rowe, J. \& Simpson, M. (1994) Lessons for planners: Facilitating sustainable communities through partnerships. Plan Canada, 34(6), pp. 16-19.

Association of Architects of Odesa (2019) City and port. Available at: http://www.aao.com.ua/category/city-andport/ (accessed 29 Mar. 2019).

Brand, D. (2007) Bluespace: A typological matrix for port cities. Urban Design International, 12(2-3), pp. 69-85.

DOI: 10.1057/palgrave.udi.9000195

Breen, A. \& Rigby, D. (1993) Waterfronts: Cities reclaim their edge. New York, McGraw-Hill.

Breen, A. \& Rigby, D. (1996) The new waterfront: A worldwide urban success story. London, Thames and Hudson.

Daamen, T. A. \& Vries, I. (2012) Governing the European port-city interface: Institutional impacts on spatial projects between city and port. Journal of Transport Geography, 27, pp. 4-13.

DOI: 10.1016/j.jtrangeo.2012.03.013

Davies, W. K. D. \& Herbert, D. T. (1993) Communities within cities: An urban social geography. London, Belhaven Press.

De Vibe, E. \& Kolstø, S. (2008) Fjordbyplanen. Oslo, Oslo kommune.

Demyanchenko, A. G. (2012) Analysis of the state and development trends of the sea trade ports of Ukraine. Applied Economics, 5, pp. 4347.

Demyanchenko, A. G. (2013) Role and structure of sea ports of Ukraine. Problems of the Economy, 2, pp. 53-59.

Fainstein, S. S. (1994) The city builders: Property, politics, and planning in London and New York. Oxford, Blackwell.

Florida, R. (2005) Cities and the creative class. New York, Routledge.

Fusco Girard, L. (2010) Sustainability, creativity, resilience: Toward new development strategies of port areas through evaluation processes. International Journal of Sustainable Development, 13(1/2), pp. 161-184. DOI: $10.1504 /$ ijsd.2010.035106
Georgison, J. P. \& Day, J. C. (1995) Port administration and coastal zone management in Vancouver, British Columbia: A comparison with Seattle, Washington. Coastal Management 23(4), pp. 265-291. DOI: 10.1080/08920759509362271

Gisle Rekdal, P. (2013) About the fjord city from the port's point of view. Portus: The Online Magazine of RETE, 13(25), pp. 1-4.

Glazyrin, V. L. (1998) Architectural planning formation of public maritime centers in the structure of Odesa and its urban agglomeration. Doctoral thesis. Kyiv, Kyiv National University of Building and Architecture.

Glazyrin, V. L. (2003) Problems and conceptual bases of perspective development of Odessa. In: Regional problems of architecture and extension of land: Collection of articles, pp. 32-40. Odesa, Astroprint.

Hasson, S. \& Ley. D. (1994a) The downtown eastside: "One hundred years of struggle." In: Neighbourhood organizations and the welfare state, pp. 172-204. Toronto, University of Toronto Press.

Hoyle, B. S. (1989) The port-city interface: Trends, problems and examples. Geoforum, 20(4), pp. 429-435. DOI: 10.1016/0016-7185(89)90026-2

Hoyle, B. S. (1998a) The redevelopment of derelict port areas. The Dock and Harbour Authority, 79(887), pp. 46-49.

Hoyle, B. S. (1998b) Cities and ports: Concepts and issues. Vegueta, 3, pp. 263-278.

Hoyle, B. S. (2000) Global and local change on the port-city waterfront. Geographical Review, 90(3), pp. 395-417. DOI: 10.2307/3250860

Hudson, B. J. (1996) Cities on the shore: The urban littoral frontier. London, Pinter.

Internet 1: https://index.minfin.com.ua/reference/people/ (accessed 29 Mar. 2019).

Internet 2: http://mayak.org.ua/news/the-experts-of-the-world-bankwas-advised-to-odessa-to-create-a-smart-port-and-to-get-rid-of-dirtygoods/ (accessed 29 Mar. 2019).

Internet 3: https://www.oslo.kommune.no. (accessed 29 Mar. 2019).

Internet 4: https://www.oslohavn.no/no/fjordbyen/om_fjordbyen/ (accessed 29 Mar. 2019).

Internet 5: http://odessastory.info/ (accessed 29 Mar. 2019).

Jacobs W., Ducruet C. \& de Langen P. W. (2010) Integrating world cities into production networks: The case of port cities. Global networks, 10, pp. 92-113. DOI: 10.1111/j.1471-0374.2010.00276.x

Khalin V. V. (2016) The concept of a combined bridge in the multimodal corridor Odessa-Reni. Arkhitekturniy vestnik KNUBA, 10, pp. 368-374.

Khalin V. V. (2017) The concept of the complex line of the electric transport the high-speed tram - The monorail in Odessa in the conditions of renovation of the port territory. The Scientific Heritage, 10(3), pp. 8-12.

Kirichenko, O. P. (2015) Transformation of the functions of a seaport under the influence of globalization processes. Problems and Prospects of Economics and Management, 2, pp. 108-112.

Krausse, G. H. (1995) Tourism and waterfront renewal: Assessing residential perception in Newport, Rhode-Island, USA. Ocean and Coastal Management, 26(3), pp. 179-203. DOI: 10.1016/0964-5691(95)00016-u

McCarthy, J. (1996) Waterfront regeneration in the Netherlands: The cases of Rotterdam and Maastricht. European Planning Studies, 4(5), pp. 545-560. DOI: 10.1080/09654319608720365 
McCarthy, J. (1998) Waterfront regeneration: Recent prac-

tice in Dundee. European Planning Studies, 6(6), pp. 731-736.

DOI: 10.1080/09654319808720493

Merk, O. (2013) The competitiveness of global port-cities: Synthesis report (OECD Regional Development Working Papers). Paris, OECD Publishing. DOI: 10.1787/5k40hdhp6t8s-en

Norcliffe, G. B., Bassett, K. \& Hoare, T. (1996) The emergence of postmodernism on the urban waterfront. Journal of Transport Geography, 4(2), pp. 123-134. DOl: 10.1016/0966-6923(96)00005-1

Oakley, S. (2011) Re-imagining city waterfronts: A comparative analysis of governing renewal in Adelaide, Darwin and Melbourne. Urban Policy and Research, 29(3), pp. 221-238. DOI: 10.1080/08111146.2011.592133

Odesa Sea Port Authority (2019) Development plans. Available at: http://www.port.odessa.ua/en/about-port/development-plans (accessed 29 Mar. 2019).

Onishchenko, V. M. (2008) Trends in the urban development of coastal areas. Modern problems of architecture and urban planning, 20, pp. 188195.

Panchenko, T. F. (1999) Prospects and directions of the resort and recreational development of the Black Sea region, regional problems of architecture and urban planning. Odesa, Astroprint.

Panchenko, T. F. \& Onischenko, V. M. (2007) Problems of development of coastal areas. Modern Problems of Architecture, 18, pp. 173-178.

Peck, J. (2005) Struggling with the creative class. International Journal of Urban and Regional Research, 29(4), pp. 740-770.

Port de Barcelona (2010) III Plan estratégico del Port de Barcelona. Barcelona.

Ports of Ukraine (2019) Available at: https://ports.com.ua/spravka/infrastruktura/odesskiy-morskoy-port (accessed 29 Mar. 2019).

Schubert, D. (2009) Ever-changing waterfronts: Urban development and transformation processes in ports and waterfront zones in Singapore, Hong Kong and Shanghai. In: Graf, A. \& Huat, C. B. (eds.) Port cities in Asia and Europe, pp. 57-85. New York, Routledge.

Schubert, D. (2011) Waterfront revitalizations, from a local to a regional perspective in London, Barcelona, Rotterdam, and Hamburg. In: Desfor, G., Laidley, J., Stevens, Q. \& Schubert, D. (eds.) Transforming urban waterfronts fixity and flow, pp. 74-97. New York, Routledge. DOI: $10.4324 / 9780203841297$

Schubert, D. (2014) Waterfront transformations and city/port interface areas in Hamburg. Revista Dimensión Empresarial, 13(1), pp. 9-20. DOI: 10.15665/rde.v13i1.335

Skachek A. M. \& Freidlin M. P. (2012) The deepwater port on Khadzhibeisky Liman of the Odessa Agglomeration. Available at: https://ports. com.ua/articles/archive/razvitie-odesskogo-porta-v-khadzhibeyskom-limane (accessed 29 Mar. 2019).

Ukrainian Sea Ports Authority (2016) Results of cargo handling for 2016 in the seaports of Ukraine. Available at: http://www.uspa.gov.ua/ru/ press-tsentr/analitika/analitika-2016 (accessed 29 Mar. 2019).

Urenev, V. P. (2003) Natural and town-planning conditions for the development of coastal areas. Regional problems of architecture and urban planning. Sat. scientific works, 5-6, pp. 23-26. Odesa, Astroprint. 